\title{
THE USING OF PICTURE STORY BOOKS TO INCREASE THE SPEAKING STUDENTS' ABILITY IN STKIP BINA INSAN MANDIRI SURABAYA
}

\author{
Sulistiyani \\ STKIP Bina Insan Mandiri Surabaya \\ sulistiyani@stkipbim.ac.id
}

\begin{abstract}
This study departs from the background of the need for using of the picture story book in improving the reading interest of students as one of the ways and creativity of teachers in the learning process in STKIP Bina Insan Mandiri. The purpose of this study is to describe the using of picture story book so as to improve the speaking skills of STKIP Bina Insan Mandiri. The students of English Education department. This type of research used classroom action research conducted in STKIP Bina Insan Mandiri Surabaya with 2 cycles which each cycle is conducted through 2 meetings. In the first cycle is some children are not yet accustomed in learning activities using picture story book so that speaking skills have not been too visible increase significantly. In the first cycle speaking skills earn $42 \%$ of the total number of students, and in the second cycle of reading interest of children increased to $81 \%$. It can be concluded that learning by using picture story book can improve the speaking skills in STKIP Bina Insan Mandiri Surabaya.
\end{abstract}

Keywords: Picture story book, speaking ability, STKIP BIM Students.

\section{INTRODUCTION}

In learning English on campus for example, a lecturer should understand the difference in judgment between the skills of Writing, Speaking, Listening and Reading skills. Please note that, in the process of assessing the learning outcomes of learners required methods or techniques and instruments that need to be considered and prepared, so that learning objectives can be achieved so as to have the right standards. Techniques and instruments used that will provide information to the lecturer on the circumstances and achievements achieved by learners who taught skills funds are different in English learning. Techniques and assessment of learning outcomes that can be developed by the lecturer can be a test type assessment, non-test, grade-based assessment, performance appraisal, as well as portfolio assessment. Methods, Techniques, and Instruments Assessment of Learning Outcomes Learners. There are several techniques and assessment tools that lecturers can use as a means of obtaining information about students' learning conditions. The use of the various techniques and tools 
should be tailored to the purpose of the assessment, the time available, the nature of the task performed by the student and the number / amount of subject matter that has been submitted. An assessment technique is a method or method of assessment that lecturers can use to obtain information about the learning conditions and achievements of learners.

In order to fulfill the needs, interest and student's sensitivity in the development of speech ability can be arranged various forms of learning activities to improve students' speaking skills especially STKIP Bina Insan Mandiri Surabaya for English education department students. Through game learning activities can encourage and stimulate speech. In order to achieve good results, the media or props play a very important role, especially in STKIP Bina Insan Mandiri, because teaching and learning activities in the classroom focused on teaching prospective lecturers who are required skilled in the use of English especially in the ability to speak. With the explanation using media will make students more understanding and interesting in teaching and learning activities in the class even more courses speaking in English. In this case researcher wants to use a learning media in the form of picture story books that can be used in improving students' speaking skills in English.

Reality fact in the field of research in the STKIP Bina Insan Mandiri Surabaya $75 \%$ of students have difficulty in speaking English fluently, This case can be seen from the results of initial observations found interest in speaking and storytelling in English, that is very less visible only $25 \%$ of students who can already talking connecting sentences and drawings, composing new vocabularies and their images, and composing words consisting of two, three or four sentences into a story in English. Speaking or telling stories in English directly either through pictures or text still requires the help of image media in order to achieve maximum results.

\section{LITERATURE REVIEW}

Using picture in the Story Book is a learning tool / medium containing messages that can reflect/illustrate the content of a story. Picture in story books are the most commonly used media. It is because generally students prefer pictures rather than writing, especially if the drawings are made and presented according to the requirements of a good image, it certainly will increase the spirit of students in following the learning. The picture in story book media is the embodiment of the imitations of objects, scenes, outpourings of ideas or ideas visualized into two dimensions (Rohani 1997: 47).

Picture in story book is a medium to convey various messages in the form 
of books that are packed in writing and pictures. In the process of learning media presence has a significant meaning. Because if in the learning activities there are lesson materials that are not understood / less clear when delivered lecturers, it needs to be assisted with the media. The complexity of instructional materials delivered to students can be clarified through the media. Media can help lecturers who are less able to say with certain words or sentences in English.

\section{Purpose of the use of picture story books}

Basically, the using of media is a substitute for real objects so as to provide an indirect experience for the target group of education: (a). As a tool in education;(b). To draw attention to a problem; (c). To remind a message or information; (d). To explain facts and actions.

Books are used to read stories (story reading) is a picture book and under the picture, there are sentences with a simple language, which explains the contents of the image. In reading the story (story reading) lecturers are not free to do such gestures on the story without a tool. Therefore, intonation and tone of voice and mantra of lecturers become the main tool in addition to the pictures and sentences in the book to help students' fantasies. The lecturer should understand and memorize the contents of the story to be read to the details. Thus avoidable something that can interfere with the concentration of students, for example every time the lecturer must flip or change the position of the book to read the text.

Characteristics of picture books, According Rahadi (2003:15) there are some characteristics of pictorial story books are: (a) Must be authentic means to describe objects / events as if students see firsthand; (b) Simply, the composition is quite clear showing the major parts of the picture; Proportional image size, so students easily imagine the actual size of the object / image object; (d) Combine the beauty with suitability to achieve learning objectives.

\section{Advantages of picture story books}

Advantages of picture story books: (a) It is concrete and more realistic in raising the subject matter when compared to the verbal language; (b) Can overcome the limitations of space and time;. (c) Clarify problems in any field and for everyone regardless of age so as to prevent or correct misunderstandings; (d) The price is cheap and easy to obtain and use.

Understanding Speech Skills are the ability to expressing opinions or thoughts and feelings to a person or group orally, either face-to-face or remotely. Teaching English includes four language skills: listening, speaking, reading, and writing. All that must be 
supported by other language elements, namely: Vocabulary, Grammar, and pronunciation in accordance with the theme as a means of purpose of learning itself. Of the four language skills mentioned above, learning speaking skills (Speaking) was less able to walk properly. The speaking ability of STKIP Bina Insan Mandiri students is generally still low, probably due to several factors. The first factor of students is still low in vocabulary mastery. Among the factors behind the students' ability to speak are vocabulary mastery. On this occasion the author will try to overcome the problem by using the picture media. By using the picture media at least students can understand the intentions contained in the picture and able to convey the idea because of the effects of interest from the picture.

The purpose of teaching conversation according to Tarigan in Rakino (2004: 31), among others: (1) Train students to bear the contents of their hearts (thoughts, feelings, and abilities) orally with regular language and good sentences. (2) Enlarge the inner impulse will bear the contents of his heart. (3) Fostering courage to converse with students. (4) Increase the vocabulary of the students. (5) From the point of psychology of humanism is to provide opportunities to students.

The using of picture story books to increase the interesting in speaking and telling stories in English. University

has a positive role in student interesting in speaking English, presenting, learning systems and methods, and providing a variety of interesting material to read. Students will not be interested in speaking in English if the class does not have books and magazines that are available. The provision of interesting reading material can be used as a starting point for the creation of an attitude to speak English.

\section{RESEARCH METHODOLOGY AND RESULTS}

\section{Research Methods}

Approach and Type of Research

This research is a classroom action research in STKIP Bina Insan Mandiri Surabaya that attempts to provide a systematic and accurate description, and can reveal an increased interest in speaking English through the picture story book in the English education department at STKIP Bina Insan Mandiri Surabaya.

According to Riyanto (2001: 49) suggests that classroom action research emphasizes activities by experimenting ideas into practice to improve or change something in order to have a real impact on it. Because collecting data in the form of numbers and give interpretation of the results so that the results of research is not the opinion of researcher but the characteristics of the symptoms studied.

\section{Research design}


The design of this classroom action research is a cycle design consisting of four stages: planning, action, observation and reflection. This classroom action research cycle is done repeatedly and continuously until the problem under study can be solved or addressed properly. This research is described as a dynamic process that includes 4 aspects of planning, action, observation and reflection, they are all sequential steps in cycle I that are related to the next cycle.

\section{Cycle I}

a. Planning (Planning)

At this stage formulated a plan that will be done to increase and improve the process and student learning outcomes so that lecturers conduct curriculum analysis to determine the basic competencies to be delivered to students by using picture story book in media that includes:

b. Implementation (Acting)

Educators as researcher carries out actions based on plans that have been planned as an effort to increase and improve student learning outcomes are expected. At this stage the action is done in the form of learning by using picture story book in media.

The steps of implementation of learning using picture story book in media as follows

1) Initial Activity:

2) Core Activities

3) Final Activity c. Observation (Observation)

Observation activities are conducted simultaneously with the implementation of the action. At this stage, the data on the implementation of the action of the plan that has been made and its impact on the process and the results of activities are collected with the tools that have been prepared. Observation activities include observations on.

d. Reflection (Reflecting)

Reflection is done through analysis and synthesis to examine, find the success or failure in the learning process achieved from the action learning that has been implemented. Further reflection results are used for consideration in the implementation of subsequent cycle improvements.

\section{Research Setting}

The research was conducted at STKIP Bina Insan Mandiri Surabaya because the researcher was a lecturer at the campus where the student was very open to receive learning innovation.

\section{Research Subject}

In this Classroom Action Research is the subject of research a student of STKIP Bina Insan Mandiri Surabaya as many as 30 students consisting of 16 boys and 14 girls.

\section{Data Collection Techniques}

Data collection techniques in this study are the results of learning, observation and documentation.

a. Observation 
Obsevation is used to observe student activity and lecturer performance during learning process. Observation is an observation that includes concentration activities on an object by using all sense activities (Arikunto: 2002: 133).

1) Format of lecturer observation sheet

Is the observation of the lecturer as a researcher used as a reference whether the researcher while conducting the learning process is in accordance with the planned implementation of learning that has been made or not.

2) Format of learning result observation sheet

Observations made on the students aims to find out the learning outcomes of students in the learning process using picture story book in media.

According Kusnandar (2008: 67) from the above observation sheet can be calculated percentage of success rate by using simple formula as follows:

$\mathrm{P}=\mathrm{f} \times 100 \%$

$\mathrm{N}$

Description: $\mathrm{P}=$ percentage of result

$\mathrm{f}=$ total of acquisition score

$\mathrm{N}=$ maximum number of scores

Finding the Average Value by using the following formula:

$\mathrm{M}=$ earnings score
Description: $\mathrm{M}=$ average value $\mathrm{N}=$ number of children

b. Documentation

collecting data by recording data / documenting learning to know the student response to learning activities through picture story book.

\section{Research Result And Discussion}

Classroom Action Research on increasing the interest of speaking students STKIP Bina Insan Mandiri Surabaya with the subject of research as many as 30 students which have been implemented through 2 cycles. with the results of the study as follows: At the first cycle meeting is to invite students to be actively involved in learning. The role of the lecturer in presenting the explanation in English is not too fast and should the explanation be conveyed with expression and intonation according to the story line. The low percentage of completeness of the desired determination or has not met the set targets that is at least $75 \%$ of students master the material then continued the meeting on cycle II.

\subsection{Observation Results}

a. Observation of Student Activity The activity of the students in the English speaking subject shows the percentage of $71 \%$ and in the second meeting increased to $92 \%$ this means that students have been motivated 
and have achieved the target as expected.

b. Observation of Lecturer's Activities Observation of lecturers conducted by peers at the time of the process of activity in the course of speaking in English meeting I produced $71 \%$ and then increased at the second meeting to get $96 \%$.

c. Observation of learning result of meeting I get the percentage of $70 \%$ and at meeting II has increased to $81 \%$ this mean does not need to continue in the next cycle because it has reached the target expected.

\section{Reflection}

Based on the observations of the researcher in the second cycle of II meeting, the result has fulfilled the target of $81 \%$. Students are getting more active in speaking, questioning, expressing ideas / ideas about stories already emerging in English. The atmosphere of effective and fun learning has begun to create. This success is related to the lecturer's mastery of the material, the lecturer's speech and story telling has used intonation, vocal characters, gestures, mimic / expression and language that attract students very much. Students are more motivated and enthusiastic in learning. This shows an increase in the student interesting in learning that has begun to appear.

This can be seen in the recapitulation of the results and comparison graphs of the results obtained below:

\begin{tabular}{|c|c|c|c|c|}
\hline \multirow[b]{2}{*}{ No } & \multirow[b]{2}{*}{$\begin{array}{c}\text { Research } \\
\text { Results }\end{array}$} & \multicolumn{3}{|c|}{ Hasil Penelitian } \\
\hline & & $\begin{array}{l}\text { Students' } \\
\text { activities }\end{array}$ & $\begin{array}{c}\text { Lecturers' } \\
\text { activities for } \\
\text { implementing } \\
9 \text { indicators } \\
\text { learning } \\
\text { outcomes }\end{array}$ & Result \\
\hline 1 & $\begin{array}{l}\text { Cycle I } \\
\text { Meeting } \\
1\end{array}$ & 50 & 4 & 42 \\
\hline 2 & $\begin{array}{l}\text { Cycle I } \\
\text { Meeting } \\
2\end{array}$ & 62,5 & 6 & 60 \\
\hline 3 & $\begin{array}{l}\text { Cycle II } \\
\text { Meeting } \\
1\end{array}$ & 77,5 & 6 & 70 \\
\hline 4 & $\begin{array}{l}\text { Cycle II } \\
\text { Meeting } \\
2\end{array}$ & 92,5 & 9 & 81 \\
\hline
\end{tabular}

\subsection{Discussion Of Result} Cycle I

In the first cycle in the early stages of the morning lecturers' materials to open lessons by conveying about the theme on that day then students are invited to listen and respond to the story with visual aids in the form of picture story books but intonation and facial expressions still look monotonous lecturer is not accustomed to telling stories with tools visual display of a picture story book that causes students not interested. Only interested students from 30 students attended. Student activity in learning shows only $50 \%$ of the number of students present so that speaking and story telling activities to increase students' speaking interest in English has not been achieved. Student 
completeness in learning only reached $42 \%$.

Basically picture story book is a tool / learning media that contains messages that can reflect / describe the content of a story. Picture story books are the most commonly used media. This is because generally students prefer pictures/images rather than writing, especially if the drawings are made and presented in accordance with the requirements of a good image, it would certainly add to the spirit of students in following the learning and stimulate to want to respond to the pictures/images in English. The picture story book in media is the embodiment of the imitations of objects, scenes, outpourings of ideas or ideas visualized into two dimensions (Rohani 1997: 47).

The picture story book is a medium to convey various messages in the form of books that are packed in writing and pictures. In the process of learning media presence has a significant meaning. Because if in the learning activities there are lesson materials that are not understood / less clear when delivered lecturers, it needs to be assisted with the media. The complexity of the lesson material presented to the students can be clarified through the media. At the beginning of the first cycle, efforts to increase interest in speaking using English students have not increased significantly. Thus it is necessary to improve learning in cycle II.

\section{Cycle II}

In the improvement activity for cycle II, the researcher uses visual aids in the form of picture story book to increase reading interest of students so that it is hoped that with cycle II. There is an increase of reading interest of students. In the second cycle in the early stages of the morning lecturers' materials opened lessons by conveying the theme at that time and then students are invited to listen to fairy tales with visual aids in the form of pictures/images in picture story book, as long as telling lecturers using English using intonation, faculty faces.

Student activity has reached $92,5 \%$ in cycle II of meeting II with percentage of learning mastery $81 \%$. This means that speaking and story-telling activities using English have shown success. Students became interested in stories that were brought by lecturer and aroused to respond to the story by using English. In addition to being able to answer questions raised by lecturer in relation to the story, the students have also been able to express their ideas about the content of the story or comment on the characters in the picture story book. So the story telling activities in raising the interest of speaking the students using English.

The using of picture story book in media for improving students 'speaking interest in English as a planned effort in improving the skills of students' 
knowledge. Speaking skills in learning is the symbol of verbal and visual symbol to get the meaning contained there in. The using picture story book in media conducted on STKIP Bina Insan Mandiri Surabaya students to increase the students' speaking interest has improved significantly. Thus the improvement of learning in cycle II is said to be successful and does not need for improvement anymore.

\section{CONCLUSIONS}

Based on the results of classroom action research that has been implemented that is from cycle I to cycle II with through the discussion and analysis can be concluded that In cycle II meeting II has experienced a significant improvement so that this research can be said successful and does not need next meeting. Through the use of picture story book in media can increase students' speaking interest in English, in cycle I, the average score reached $42 \%$ to $81 \%$ in cycle II of the existing indicators.

\section{REFERENCES}

Andi Yudha. 2007. Cara pintar mendongeng. Bandung : Mizan.

Depdiknas. 2004. Kurikulum Berbasis Kompetensi TK. Jakarta : Direktorat Jendral Pendidikan Dasar dan Menengah.

Depdiknas. 2007. Pedoman dan Pelaksanaan Bidang Pengembangan Kemampuan Berbahasa. Jakarta:
Direktorat Jendral Pendidikan Dasar dan Menengah

Fahmi Mustofa. 2005. Agar anak gemar membaca. Bandung : Mizan.

Hurlock, Elizabeth. 2003. Perkembangan Anak. Jakarta: Erlangga.

Hernowo. 2006. Menjadi Guru Kreatif. Bandung: MIC.

Kusnandar. 2008. Langkah Mudah Penelitian Tindakan Kelas. Jakarta: Raja Grafindo Persada.

Mustamir. 2009. Saatnya Bersekolah. Yogyakarta : Mizan.

Moeslichatoen. 2004. Metode Pengajaran di Taman kanak- kanak. Jakarta : Rinneke Cipta.

Mustaqim dan Abdul Wahab. 1990. Psikologi Pendidikan. Jakarta : Rinneke Cipta.

Reni Kabar Hamidi. 2001. Psikologi perkembangan Anak. Jakarta: Grasindo.

Riyanto, Yatim. 2007. Metodologi Penelitian Pendidikan. Surabaya: SIC.

Sardiman. 2007. Interaksi dan Motivasi belajar Mengajar. Jakarta: Raja Grafindo Persada.

Sugiyono. 2009. Metode Penelitian Pendidikan. Bandun : Alpabeta. Suyatno. 2005. Permainan Pendukung Pembelajaran Bahasa dan sastra. Jakarta: PT. Grasindo. 